\title{
「大規模都市公園の役割と展望」特集にあたって
}

\section{Development and Future Prospect of Large-scale Park}

\author{
特集企画担当編集委員 舟引 敏明
}

\section{特集の趣旨}

1972 年に都市公園等整備五ヶ年計画が創設され，その 中の重点項目として大規模公園が位置づけられた。引き続 き 1974 年に, 首都圈での最初の大規模国営公園である国 営武蔵丘陵森林公園が開園し，大規模な都市公園の姿を現 実のものとした。さらに 1977 年の緑のマスタープラン制 度の創設により都市公園の計画的な配置が進められるよう になった。この中で大規模公園も計画的に位置づけられる こととなり, 以後大規模公園の整備が急速に進められるこ とになった。これは, 都市住民のレクリエーションの場を 都市近郊に確保するという役割を持つばかりでなく，それ まで大都市圈整備計画に基づく近郊緑地保全地区等で守ら れてきた都市近郊林を積極的に公園として確保する役割を 持つ大きな転回点でああった。

大規模公園は抒打む称 $50 \mathrm{ha}$ 以上の規模を持つ都市公園 で, 主に国が整備する国営公園と都道府県や大都市が整備 する都市公園がある。大規模公園は，その規模の大きさか ら様々な自然資源を包含するとともに，大規模イベントを はじめ多岐にわたる利用者のアクティビティを容認するこ とができる。この点で，それまで進められてきたコミュニ ティタイプの都市公園と性格が異なるため, 我が国の公園 緑地整備の中で独自の役割を担うこととなり, 長寿社会を 迎える今後も福祉との連携などその役割はますます增加し ていくものと予想される。また, その計画・整備には多く の時間と費用を要し, 地域経済振興の視点といった観点で の整備効果も見逃すことはできない。

一方で, 大規模公園の整備については近年急速に進めら れてきたため, その効果, 役割については, 行政関係の資 料を除き総括的に報告された例は少ない。本特集では，こ のような大規模公園のこれまでの実績を探るとともに，果 たしてきた役割を改めて整理し, 今後の展開方向を探ろう とするものである。

\section{特集の構成}

本特集では大規模公園の持つ全体像を理解いただくこと
を目的に，大規模公園を巡る様々な局面を紹介しょうと試 みている。

1) 最初の 4 編は総論である。

まず，大規模公園計画の視点について計画論の観点から 之緑地保全の観点加ら論じ，さらに大都市圈計画と大規模 公園の関係を論じている。次に，大規模公園の喨矢となっ た国営公園についての実績と展望について論じている。

2 ）次に，大規模公園の効果や役割についての各論である。 最初に，大規模公園のもたらした効果を見るために，様々 な国家的イベントの舞台となった大規模公園の役割につい て，そして大規模公園が地域経済にもたらした効果につい て論じている。

さらに，ランドスケーププランナーの視点からの設計・ 計画の特色とあり方について論じている。また，大規模公 園の開設に伴いその役割が大きく变化した大規模公園の管 理手法について論じている。

3 ）第三は具体的な事例の紹介である。

国営公園における環境教育について, 県レベルにおける 大規模公園の配置計画の事例, 県が整備した特色ある大規 模公園の事例等を紹介している。

\section{おわりに}

紙面の関係から，大規模公園の持つ様々な側面を概観す るにとどまっているが，大規模公園の持つ全体像と新たな ランドスケープのフィールドとしての大規模公園の可能性 をご理解いただければと考えている。執筆いただいた方々 に改めて感謝を申し上げる。

大規模公園の規模の大きさは, 緑地保全, レクリエーショ ンそしてまた新たなアクティビティを許容するものであ り，これからの進め方次第では我が国の大きな未来への資 産となりうるあのである。その意味で, 会員の今後の大規 模公園への積極的な関与と関心を喚起する一助となれば目 的の過半は達したと考えるあのである。 